\title{
Ocorrência de Ascia monuste orseis (Lepidoptera: Pieridae) danificando mudas de Crataeva tapia
}

\author{
Occurrence of Ascia monuste orseis (Lepidoptera: Pieridae) in Crataeva tapia seedlings
}

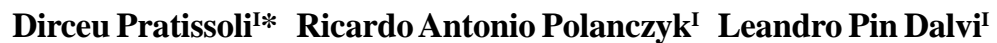 \\ Julieder Goronci Cocheto ${ }^{\mathrm{I}}$ Debora Ferreira Melo ${ }^{\mathrm{I}}$
} \begin{abstract}
O objetivo deste trabalho é comunicar a ocorrência
da curuquerê-da-couve, Ascia monuste orseis (Godart) RESUMO (Lepidoptera: Pieridae), causando danos a Crataeva tapia (L.) (tapiá). Mudas de tapiá, com cerca de $25 \mathrm{~cm}$ de altura, foram severamente atacadas por lagartas da curuquerê-dacouve, que causaram $100 \%$ de desfolha, além de alimentaremse da epiderme do caule em estrutura primária (casca), o que causou a morte de todas as mudas.
\end{abstract}

Palavras-chave: praga das crucíferas, curuquerê-da-couve, tapiá, danos florestais.

\section{ABSTRACT}

This research is aimed at comunicating the occurrence of cabbage caterpillar Ascia monuste orseis (Godart) (Lepidoptera: Pieridae), causing damage to Crataeva tapia (L.) ("tapiá"). It was verified $100 \%$ of desfoliation indicating that these larvae caused severe damaged to "tapiá". Besides this, they consumed epidermis causing death of all seedlings.

Key words: brassicae pest, brassicae wimworm, tapia, forest damage.

O reflorestamento pode ter várias finalidades, entre elas a preservação da floresta nativa e a recuperação de áreas degradadas, sendo necessária a escolha correta das espécies a serem empregadas em cada situação (HIGA \& HIGA, 2000).

Crataeva tapia é uma planta da família Caparidaceae, que ocorre desde Pernambuco até São
Paulo e Minas Gerais (Zona da Mata), na mata pluvial Atlântica e no Pantanal Mato-grossense, sendo chamada popularmente de cabaceira, cabeceira, cabaceira-do-pantanal e pau-d'alho, porém é mais conhecida como tapiá. Sua madeira tem sido empregada na construção civil, em forros, caixotaria e confecção de canoas. As flores são apícolas, os frutos são comestíveis e muito apreciados pela fauna. Frutos, cascas e folhas são considerados de valor medicinal. A árvore possui atributos ornamentais que a recomendam para arborização paisagística. Também é recomendada para reflorestamentos destinados à recuperação de áreas degradadas (LORENZI, 2002).

A curuquerê-da-couve, Ascia monuste orseis (Godart, 1818), que tem como sinonímia os nomes de Ascia monuste monuste (L., 1764), Pieris monuste (L., 1764) e Pieris monuste orseis (Godart, 1818), é um lepidóptero da família Pieridae, e ocorre em todos os Estados brasileiros. As lagartas desfolham a couve, sendo considerada a principal praga dessa cultura; no entanto, pode ocorrer em outras crucíferas, tais como repolho, couve-flor e couve-chinesa (CAVALCANTE, 1983; MEDEIROS et al., 1998).

O viveiro de essências nativas do Centro de Ciências Agrárias da UFES (CCA-UFES), localizado no município de Alegre - ES, foi implantado para atender o projeto de recuperação florestal da Bacia do Rio Itapemirim, pois esta área apresenta um processo de degradação avançado. As áreas selecionadas para fazer

'Universidade Federal do Espírito Santo (UFES), Centro de Ciências Agrárias, Departamento de Produção Vegetal, Alto Universitário s/nº, CP 16, 29500-000, Alegre, ES, Brasil. E-mail: pratissoli@cca.ufes.br. * Autor para correspondência. 
o processo de recuperação apresentavam naturalmente uma grande variedade de espécies vegetais nativas e, dentre essas, o tapiá.

Durante a fase em que as mudas de tapiá estavam no viveiro de aclimatação e apresentavam de uma a duas folhas trifoliadas, apresentaram ataque severo de lagartas da curuquerê-da-couve, com 100\% de destruição das mudas. O acompanhamento do comportamento da praga permitiu verificar que os adultos faziam suas posturas na face superior dos folíolos (adaxial), ao contrário do que ocorre nas crucíferas, nas quais a postura é feita na face inferior das folhas (abaxial), sendo os ovos depositados agrupadamente.

As lagartas recém-emergidas migraram para a face inferior dos folíolos, onde passaram a raspar o limbo foliar. Com o seu desenvolvimento larval, as mesmas passaram a se alimentar de todo o folíolo e, posteriormente do pecíolo. No final do desenvolvimento larval, passaram a destruir a gema apical e, posteriormente, a se alimentarem da epiderme do caule em estrutura primária (casca), chegando até a base do coleto da muda, possivelmente pela falta de massa foliar para se alimentarem. Com o desenvolvimento larval completo, as lagartas migraram para a tela do viveiro, onde ocorreu a transformação para pupa. No entanto, observou-se que algumas lagartas empuparam na própria planta.

Para a identificação específica dessa praga, lagartas e pupas foram coletadas no viveiro e enviadas ao Laboratório de Entomologia do CCA-UFES, onde permaneceram acondicionadas em gaiolas de tela, tipo nylon (40x 40x 40cm), em sala climatizada a $25 \pm 1^{\circ} \mathrm{C}$, UR
$70 \pm 10 \%$ e fotofase de 14 horas, até a emergência dos adultos, quando foi feita a confirmação de Ascia monuste orseis.

Provavelmente, o ataque dessa praga em plantas de tapiá ocorreu devido à existência de um plantio de couve de 0,5 ha a 200 metros do viveiro de mudas. No período em que foram feitas as mudas de tapiá, o plantio de couve estava no final do ciclo e abandonado, apresentando insetos-praga como curuquerê, pulgão e mosca branca. Dessa forma, é comum a dispersão e busca de hospedeiros alternativos que ofereçam condições para manter a população. Porém, este fato geralmente ocorre em plantas da mesma família e não como foi descrito neste trabalho. Sendo assim, esta espécie de inseto poderia se tornar uma potencial praga na cultura do Tapiá.

\section{REFERÊNCIAS}

CAVALCANTE, R.D. Dicionário de entomologia. Brasília: Editerra, 1983. 802p.

HIGA, A.R.; HIGA, R.C.V. Indicação de espécies para reflorestamento. In: GALVÃO, A.P.M. Reflorestamento de propriedades rurais para fins produtivos e ambientais: um guia para ações municipais e regionais. Brasília: EMBRAPA, 2000. p.101-124.

LORENZI, H. Árvores brasileiras: manual de identificação e cultivo de plantas arbóreas nativas do Brasil. 2.ed. São Paulo: Instituto Plantarum, 2002. 367p.

MEDEIROS, M.A. et al. Bibliografia brasileira de entomologia das hortaliças. Brasília: Embrapa-Spi/ EmbrapaCnph, 1998. 186p. 